Review

\title{
Production of Biosolids by Autothermal Thermophilic Aerobic Digestion (ATAD) from a Municipal Sewage Sludge: The Polish Case Study
}

\author{
Izabela Bartkowska *(D), Paweł Biedka and Izabela Anna Tałałaj \\ Department of Water Supply and Sewerage, Bialystok University of Technology, Wiejska 45A Street, \\ 15-351 Bialystok, Poland; p.biedka@pb.edu.pl (P.B.); i.talalaj@pb.edu.pl (I.A.T.) \\ * Correspondence: i.bartkowska@pb.edu.pl; Tel.: +48-085-746-9649
}

Received: 30 September 2020; Accepted: 23 November 2020; Published: 27 November 2020

\begin{abstract}
This manuscript analyzed the process of autothermal thermophilic aerobic digestion (ATAD) used in installations of municipal sewage treatment plants in Poland. Additionally, solutions for sludge management and the parameters of operating installations were presented. Attention was also put to the energy consumption of the process, where the energy consumption for $1 \mathrm{~m}^{3}$ of sludge treated was between 18.4 and $27.79 \mathrm{kWh}$. The amount of sewage flowing into the analyzed plants was between 1500 and $14,000 \mathrm{~m}^{3} / \mathrm{d}$. On the basis of research carried out in the years 2003-2019 in the selected plants, the characteristics of sludge after the ATAD process were presented. The parameters that determine the usefulness of the sludge as an organic fertilizer were indicated above all. The content of total nitrogen, which was from 2.4 to $8.1 \%$ of dry matter, ammonium nitrogen, which was from 0.8 to $1.8 \%$ of dry matter, and total phosphorus, which was from 1.1 to $4.2 \%$ of dry matter, recommended using sludge for fertilization. It was also pointed out that sewage sludge should be regularly tested for the dynamics of changes in chemical composition and biological parameters. These are the factors that increase risk and limit the use of sludge for fertilization.
\end{abstract}

Keywords: autothermal thermophilic aerobic digestion; ATAD; organic fertilizers; sewage sludge; natural utilization

\section{Introduction}

Municipal wastewaterand sludge treatment plants are an essential element of surface water protection systems. However, they cause a real nuisance to the surrounding environment in terms of water and air quality, acoustic climate, or soil protection. One of the problems is the generation of a significant amount of different types of waste. These include municipal sewage sludge. The increasing amount of them forces the search for methods of their final disposal. It is estimated that in 2020, about 13 million tonnes of sewage sludge will be generated in European Union countries [1].

Sewage sludge is subject to the Directive of the European Parliament and of the Council of 19 November 2008 2008/98/EC on waste (the so-called waste framework directive). According to this directive, sludge is a waste and must be subject to a specific hierarchy of processing. First of all, it is necessary to prevent the generation of waste, continue to prepare it for reuse, recycle it, use other utylization methods, and finally dispose of it. However, it is not possible to prevent the formation of sewage sludge, as it is a type of waste that cannot be avoided [2]. Therefore, further priorities in the waste hierarchy are important, i.e., preparation for reuse or final disposal.

The recycling of sewage sludge is already regulated by the previous directive 86/278/EEC of 12 June 1986. According to this directive, sludge can be used on the ground in a way that protects plants, soil, and groundwater as well as animal and human health. Closed-loop recycling schemes and new 
European legislation encourage the agricultural use of sewage sludge. This is a method of low-cost sludge disposal [1].

For the sake of circular economy (CE) policy, one of the key elements of a resource-efficient and environmentally friendly society is recycling, which reduces costs and dependence on natural resources, reduces waste generation, and stimulates economic growth. From this point of view, sludge can be valued as a secondary raw material and used as a valuable source of nutrients and organic matter [3].

However, the reuse of sewage sludge is only possible if it is stabilized and sanitary safe. Therefore, studies are necessary on end-of-waste criteria for sludge-derived products [4]. One of the processes for the recovery of stabilized and hygienized sludge is autothermal thermophilic stabilization (ATAD).

The aim of this study was to systematize the knowledge concerning the process of autothermal thermophilic stabilization of sewage sludge, which is the result of experience, resulting from participation in the design, installation, technological start-up, and operation of existing facilities. The presented material was developed on the basis of many years of research carried out in eleven municipal sewage treatment plants, in which sewage sludge is processed in the process of autothermal thermophilic stabilization. The review and evaluation of the results of the research will serve to realize that in accordance with the assumptions of sustainable development, the sewage sludge produced in the analyzed sewage treatment plants should be treated not as a waste but as a source of recovery of nutrients.

\section{The Process Characteristic}

The thermophilic stabilization of sewage sludge is used mainly in Western European and North American countries. In Germany, this system is known as ATS (die aerob-thermophile Schlammbehandlung), in the United States and Canada, it is known as ATAD (autothermal thermophilic aerobic digestion). All of the above-mentioned process solutions are based on the natural phenomenon of exothermal oxidation of organic carbon with forced air supply.

The thermophilic stabilization technology, which is used in treatment plants in Poland, was developed by Hubert K. E. Fuchs. In the 1970s, the first installation was built in Germany in Vilsbiburg, which is still operating today. Outside Western Europe, such plants operate in the USA, Canada, and Japan [5].

An essential role in the process of thermophilic stabilization is played by microorganisms, which enable the decomposition of organic compounds contained in sewage sludge. It basically takes place in two stages. The hydrolysis of complex organic compounds (proteins, carbohydrates and fats) as well as cell hydrolysis of dying microorganisms occurs in the first stage. These phenomena are caused by extracellular enzymes produced by thermophilic bacteria. In the second stage, thermophilic microorganisms oxidize the water-soluble hydrolysis products to low-energy compounds. These reactions are accompanied by heat release, and the final substances of these changes are $\mathrm{CO}_{2}$, $\mathrm{H}_{2} \mathrm{O}$, and $\mathrm{NH}_{3}$ [6-8]. The process is shown in Figure 1.

The composition of the thermophilic process microflora differs from conventional activated sludge. First of all, it does not contain nitrifying bacteria, flocculating organisms, protozoa, and other forms of life [9]. The thermophilic microbial population replaces the organisms of the raw sludge. It is a fairly homogeneous microflora, which more than 95\% consists of Bacillus, Thermus, or Actiomycestes $[9,10]$. Most strains belong to the species Bacillus stearothermophilus, which are active in the temperature range $40-80^{\circ} \mathrm{C}$. The remaining microflora are usually mixed cultures. In addition to the typical thermophilic microflora, there are thermotolerant mesophilic and extremely thermophilic bacteria, including the genus Thermus $[9,11]$. Usually, they have the ability to reproduce quickly, and the demise of thermophilic cells is equally rapid with the simultaneously occurring autolysis process. 


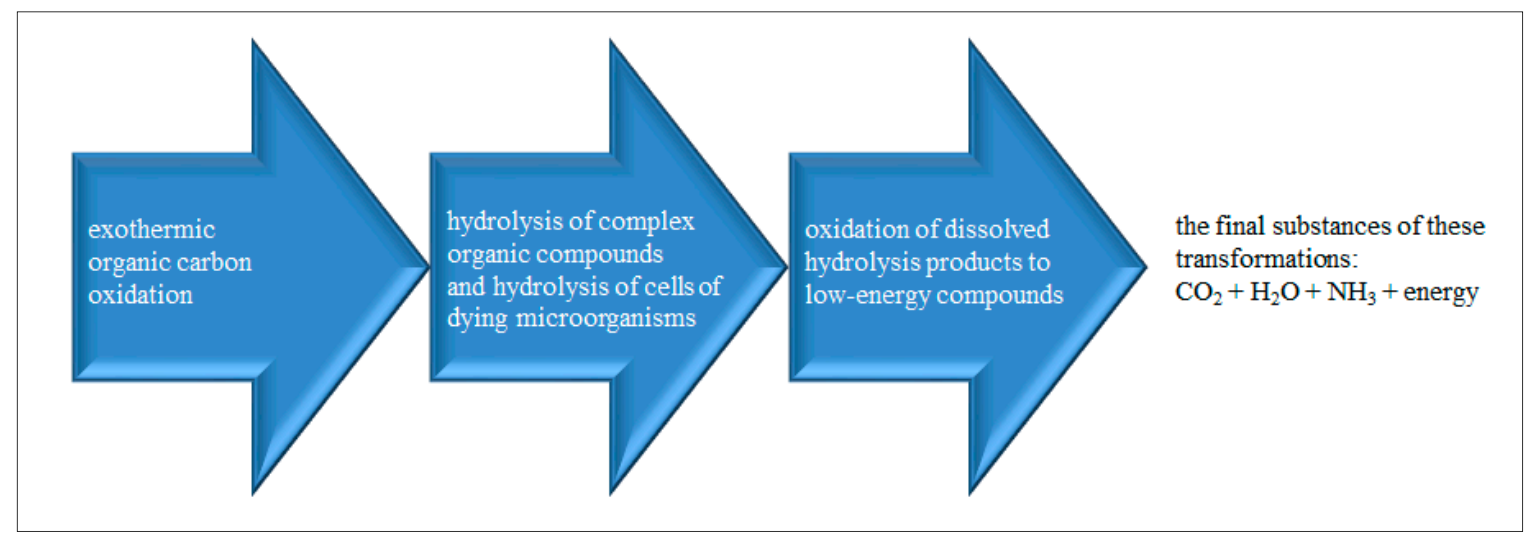

Figure 1. The autothermal process of thermophilic digestion.

The primary source of carbon and energy for thermophilic bacteria are fatty acids from hydrolysis products, while amino acids are their main source of nitrogen. Thermophilic bacteria are also resistant to the action of products of metabolism and have the ability to adapt to small amounts of oxygen. The intensive increase in the number of thermophilic bacteria, without the need to inoculate the sludge with a specific microflora, the rapid biodegradation of the substrate, the low sensitivity to temperature fluctuations, and the resistance to periodic interruptions in the aeration of the system guarantee even in emergency situations an extremely stable and flexible biological system in a thermophilic stabilization environment [12].

The processes taking place during autothermal thermophilic stabilization are in a way a continuation of the processes taking place in the active sludge, in which the oxidative biodegradation of organic substances and their mineralization takes place and parallel to the biosynthesis of cell substances. The role of aerobic heterotrophic microorganisms is taken over by thermophilic microflora. Direct oxidation of the biodegradable matter to carbon dioxide and water continues. The decomposed substances are used to synthesize new organisms, and then, the cellular material is oxidized.

The heat generation in the ATAD reactor depends on the amount of organic matter contained in the sewage sludge. As the biological load increases, the temperature increases as well. However, increasing the load with the biodegradable organic matter does not cause a proportional increase in sludge temperature. First of all, the process becomes a system with limited oxygen transfer. The rate of oxygen uptake by thermophilic organisms is very high. This results in a reduction in the amount of oxidized organic substances and a consequent temperature stabilization. In addition, temperature has a significant influence on the amount and activity of thermophilic microflora. It was found that temperature increase above $65^{\circ} \mathrm{C}$, caused by increasing load on the system, inhibit the life processes of thermophilic microflora $[6,8,13,14]$. This reduces the amount of organic compounds removed and at the same time stabilizes the process temperature. These relationships can be described as self-regulation, which makes the system stable.

Thermophilic microorganisms need more energy than e.g., mesophilic ones to maintain their life processes. Of the total amount of energy that is generated during the ATAD process, most of it is used during the metabolic changes of the microorganisms. Much less energy is used to build new cells. For this reason, processes occurring at higher temperatures are characterized by relatively low biomass production.

With the development of the thermophilic bacteria population, the foaming of the sewage sludge appears. The dying cells of these microorganisms release intracellular matter, causing a reduction in surface tension, contributing to the formation of significant amounts of foam. The formation of foam indicates that the process proceeds properly. The foam layer improves oxygen transmission, which effectively increases process efficiency and biological activity. Foam is produced in the form of cell proteins, and oily and fatty substances are destroyed. It is within the foam that the highest biological activity is observed $[15,16]$. Significant biological activity within the foam layer contributes 
to the high oxygen utilization efficiency. In addition, it provides an insulating layer above the surface of the liquid that helps maintain the temperature of the sludge. However, for operational reasons, the foam formation process must be controlled, in particular its thickness and, in a sense, its density. The foam layer of a certain height and density is kept continuously due to the use of mechanical devices.

The air discharged from the autothermic thermophilic stabilization chambers contains compounds that are odor-intensive and bothersome. It is mainly ammonia and products of decomposition and includes the incomplete oxidation of organic substances [17]. Ammonia is created as a result of the ammonification of proteins and is the main cause of the nuisance smell of the process. In addition to ammonia, reduced sulfur compounds (e.g., hydrogen sulfide, mercaptans, dimethyl sulfide), aldehydes, ketones, volatile fatty acids, thialcohols, and others $[18,19])$ are observed. The formation of offensive odor compounds is favored by the oxygen deficit caused by the high temperature of the process and the associated low redox potential [20].

\subsection{Technical Process Solution}

The process of autothermal thermophilic stabilization is usually carried out in tanks connected in series. The installation of two or more cylindrical tanks made of steel, concrete, or plastic are used. In order to minimize heat loss, the reactors are thermally insulated and closed. The design of a typical ATAD plant reactor is shown in Figure 2.

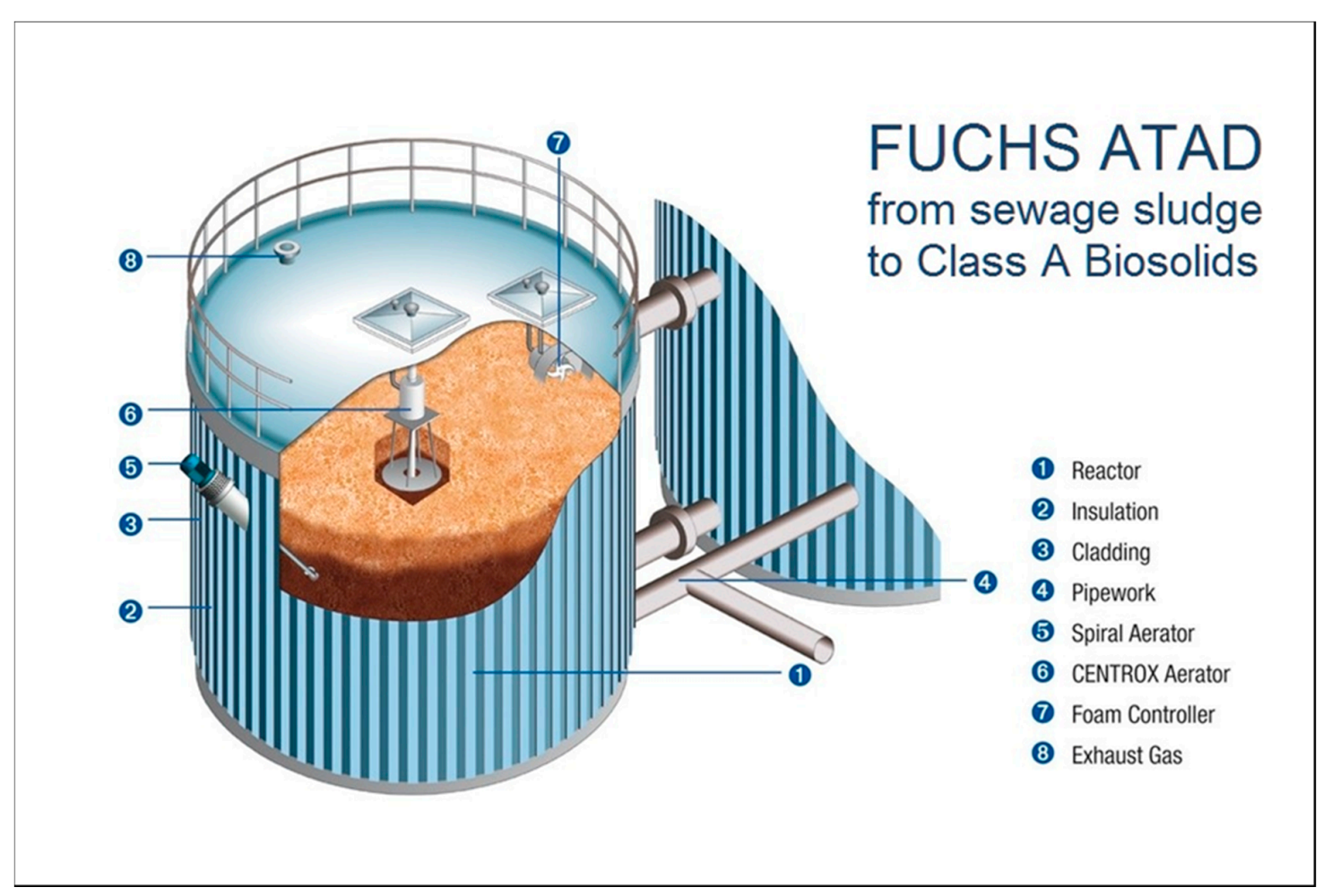

Figure 2. Operation of the autothermal thermophilic aerobic digestion (ATAD) reactor [21].

With the tanks connected in series, the temperature in the first stage of the installation is obtained in the lower thermophilic decomposition range $\left(40-48^{\circ} \mathrm{C}\right)$, with maximum disinfection and the highest temperature is obtained in the last stage $\left(55-60^{\circ} \mathrm{C}\right)$ [22]. The daily discharge of inactivated sludge takes place only from the last stage. With the end of the next discharge completed, raw sludge is fed to the first stage, while the partially treated sludge is moved to the next reactor. After feeding the sludge, the reactors remain isolated for $23 \mathrm{~h}$, at which point thermophilic decomposition occurs. In order to limit the temperature rise, a heat exchanger can be installed in the last reactor. A diagram of a sludge node with ATAD installation is shown in Figure 3. 


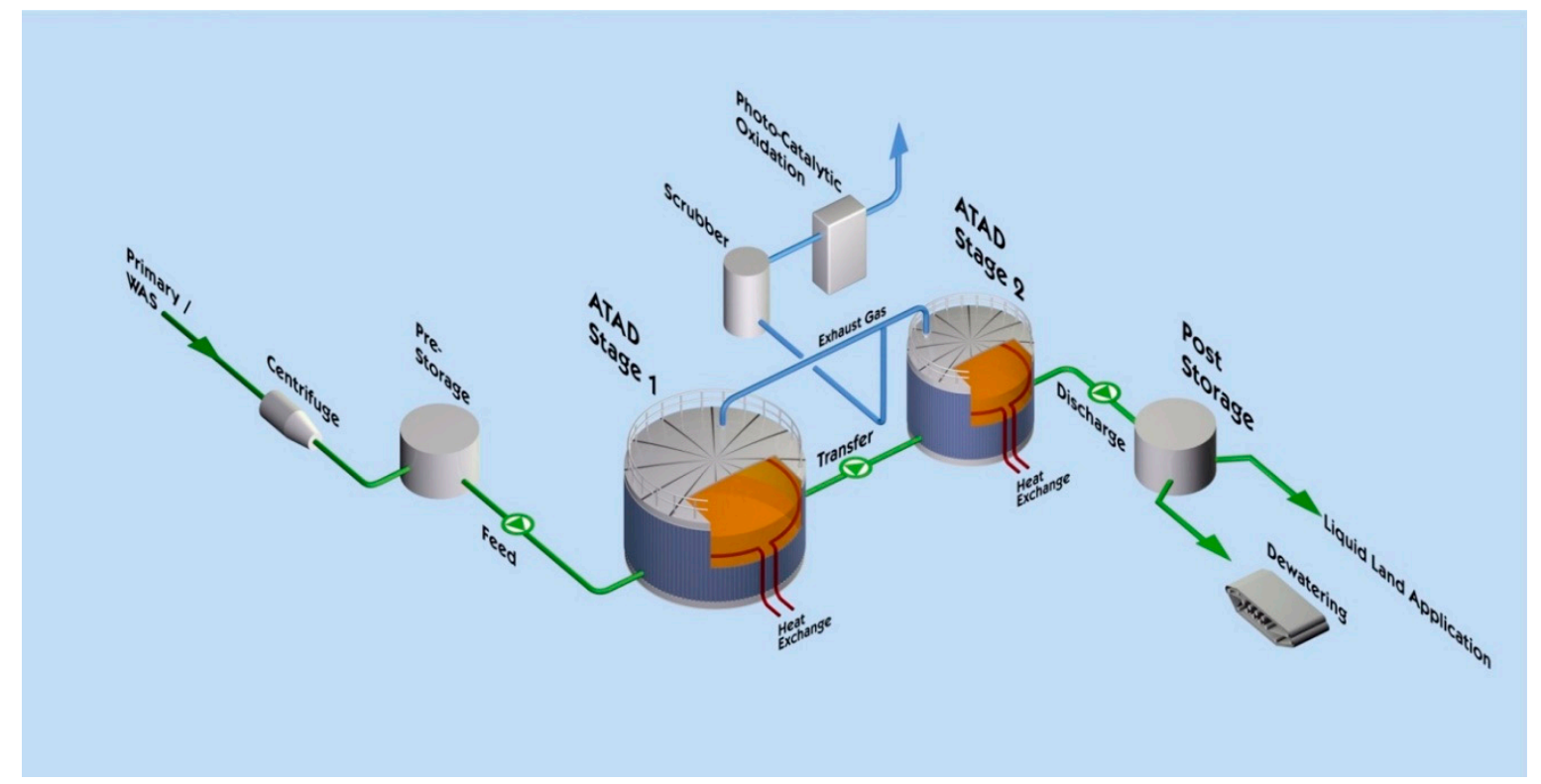

Figure 3. Diagram of a sludge node with autothermal thermophilic aerobic digestion (ATAD) [21].

The ATAD installation may also consist of three reactors. Three reactors enable the installation to operate in two- and three-stage systems. In a two-stage system, two of the reactors work in parallel as the first stage, and the third as the second stage. In a three-stage system, reactors operate in series as successive stages.

Side and central aerators ensure a constant supply of air and effective mixing of the reaction chamber contents. In some solutions, oxygen is introduced into the reactors, alone or simultaneously with air, thus slightly improving the process, but significantly increasing its operating costs.

The important thing is to regulate the amount of foam produced. This process does not aim to completely eliminate the foam, as its presence brings a number of benefits by using e.g., foam breakers, thus controlling the thickness and density of the foam layer. The mechanical operation of these rotating units cuts the foam, which is then discharged to the surface of the sludge in the reactor as a liquid and mixed with the entire content. The formation of foam should not be regulated by limiting the amount of air supplied, as there is a risk of oxygen deficiency and increased odor nuisance of sludge and gases caused by the production of excessive amounts of fermentation products.

The thermophilic stabilization system requires a system for cleaning the polluted air discharged from the reactors before it is released into the atmosphere. The most commonly used are water scrubbers (to remove mainly ammonia), biofilters, and chambers where the photocatalytic oxidation of odor generating substances takes place.

\subsection{Implemented Sludge Management Solutions}

The process of autothermal thermophilic sludge stabilization is of fundamental importance in the management of a sewage treatment plant. Before being fed into the reactors, the sludge must be thickened and collected in sufficient quantity. In turn, processed sludge needs to be cooled down before it can be finally dewatered. In addition, the air from space above the sludge must be purified before it is discharged into the atmosphere. All of this requires functionally designed and efficient facilities and equipment.

Obtaining the required degree of sludge density is not possible as a result of gravity forces alone. Mechanical devices are used in all the plants in question. Most often, the sludge thickening process takes place in centrifuges (in case of nine sewage treatment plants). In other facilities, a table and drum thickener was used. The condensed sewage sludge goes to the ATAD installation, which is discussed in detail below. 
The temperature of sludge discharged from the ATAD installation is high: up to $55-60{ }^{\circ} \mathrm{C}$. It must be cooled down before being fed into the drainage unit. Recovered heat energy can be used to heat up the compacted sludge or in other sludge treatment facilities.

In the discussed sludge treatment plants and centrifuges (in nine treatment plants), a filter press and a dewatering press were used for dewatering. Dehydrated sludge is transported to the storage yard. Sludge thickening and dewatering equipment are located in the sludge mechanical treatment building. In order to optimize the operation of sludge management equipment in the analyzed sewage treatment plants, multifunctional tanks were made. In such tanks, sludge is collected before the thickening process. The ATAD sludge is also discharged into the multi-purpose tank for cooling.

The treatment plants in question use water scrubbers to remove mainly ammonia and devices in which the photocatalytic oxidation (PCO) of substances responsible for odor formation takes place. The process is shown in Figure 4.

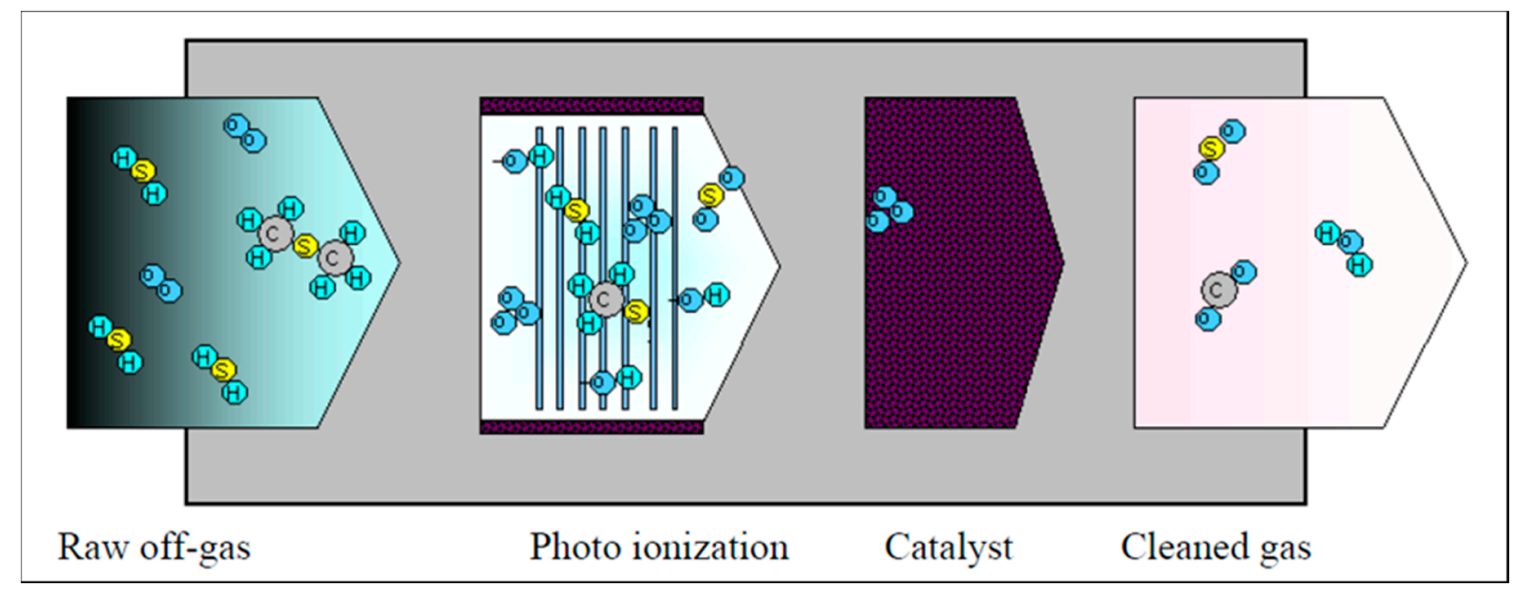

Figure 4. Scheme of photocatalytic oxidation [23].

The process is particularly effective for oxidizing pollutants and changing stench loads. Limited requirements for the operation and control of photoionization, small overall size of the installation, combined with its high efficiency, decided to use this process in the sewage treatment plants in question.

\subsection{Selected Technical and Technological Parameters of the Implemented Installations}

Since 2003, 11 installations of autothermal thermophilic sediment stabilization have been built in Poland. All of them operate in municipal sewage treatment plants. They have been designed for various sizes of treatment plants with a capacity of 1500 to $14,000 \mathrm{~m}^{3} / \mathrm{d}$. The range of wastewater treatment plant capacity in terms of population equivalent ranges from 8900 to 77,900 . The amount of sludge produced in these plants ranges from 800 to $5000 \mathrm{~kg}$ of dry matter per day.

Sludge generated during wastewater treatment is highly hydrated and contains a small amount of total solids. For the autothermic stabilization process, a pre-compaction of the sludge to about $5 \%$ of total solids is required, resulting in higher unit contents of volatile solids, which should be 65 to $70 \%$ of total solids and not less than $40 \mathrm{~g} / \mathrm{L}$, which is expressed as a chemical oxygen demand (COD). By keeping the dry mass contents in the sludge fed to the first stage rector at this level, many operational problems are avoided. The reactors are fed in batches once per day. In these wastewater treatment plants, the amount of sludge feed ranges from 17 to $97 \mathrm{~m}^{3} / \mathrm{d}$. Selected technical and technological parameters of the reactors are shown in Tables 1 and 2. 
Table 1. Technical and technological parameters of two-stage reactors.

\begin{tabular}{|c|c|c|c|c|c|c|c|}
\hline \multirow[b]{2}{*}{$\begin{array}{l}\text { Subsequent } \\
\text { Treatment } \\
\text { Plants } \\
\text { (WWTP) }\end{array}$} & \multirow{2}{*}{$\begin{array}{l}\text { Population } \\
\text { Equivalent }\end{array}$} & \multirow{2}{*}{$\begin{array}{c}\text { Average } \\
\text { Daily Plant } \\
\text { Capacity } \\
\text { ATAD } \\
\left(\mathrm{m}^{3} / \mathrm{d}\right)\end{array}$} & \multicolumn{3}{|c|}{ Reactor Dimensions (m) } & \multirow[b]{2}{*}{$\begin{array}{l}\text { Reactor } \\
\text { Useful } \\
\text { Capacity } \\
\left(\mathrm{m}^{3}\right)\end{array}$} & \multirow[b]{2}{*}{$\begin{array}{l}\text { Hydraulic } \\
\text { Retention } \\
\text { Time (d) }\end{array}$} \\
\hline & & & $\begin{array}{l}\text { Internal } \\
\text { Diameter }\end{array}$ & $\begin{array}{c}\text { Total } \\
\text { Height }\end{array}$ & $\begin{array}{l}\text { Filling } \\
\text { Height } \\
\text { with } \\
\text { Sludge }\end{array}$ & & \\
\hline WWTP_a & 77,200 & 135 & 8.40 & 4.00 & 3.35 & 185 & 8.2 \\
\hline WWTP_b & 22,690 & 34 & 7.71 & 3.60 & 2.80 & 130 & 7.65 \\
\hline WWTP_c & 28,300 & 40 & 8.50 & 3.50 & 2.70 & 153 & 7.66 \\
\hline WWTP_d & 35,000 & 27 & 8.00 & 3.30 & 2.50 & 125 & 9.3 \\
\hline WWTP_e & 10,500 & 30 & $\begin{array}{c}9.20 \\
6.50^{1}\end{array}$ & $\begin{array}{c}3.52 \\
3.52^{1}\end{array}$ & $\begin{array}{c}2.70 \\
2.70^{1}\end{array}$ & $\begin{array}{c}180 \\
90\end{array}$ & 9.3 \\
\hline WWTP_f & 39,900 & 46 & 9.42 & 3.80 & 3.00 & 209 & 9.1 \\
\hline WWTP_g & 11,300 & 16.7 & 6.00 & 3.40 & 2.60 & 73.5 & 8.8 \\
\hline
\end{tabular}

In the plants listed in Table 1, the reactors operate in series as a two-stage system. The WWTP_a plant consists of six reactors operating in three process lines of two reactors each connected also in series. In the WWTP_e plant, the first stage reactor has doubled capacity. This allows for an increased intensity of organic matter decomposition in this reactor to obtain higher temperatures.

Table 2. Technical and technological parameters of three-reactor installations.

\begin{tabular}{|c|c|c|c|c|c|c|c|}
\hline \multirow{2}{*}{$\begin{array}{l}\text { Subsequent } \\
\text { Sludge } \\
\text { Treatment } \\
\text { Plants } \\
\text { (WWTP) }\end{array}$} & \multirow[b]{2}{*}{$\begin{array}{l}\text { Population } \\
\text { Equivalent }\end{array}$} & \multirow{2}{*}{$\begin{array}{c}\text { Average } \\
\text { Daily Plant } \\
\text { Capacity } \\
\text { ATAD } \\
\left(\mathrm{m}^{3} / \mathrm{d}\right)\end{array}$} & \multicolumn{3}{|c|}{ Reactor Sizes (m) } & \multirow{2}{*}{$\begin{array}{c}\text { Useful } \\
\text { Reactor } \\
\text { Capacity } \\
\left(\mathrm{m}^{3}\right)\end{array}$} & \multirow[b]{2}{*}{$\begin{array}{l}\text { Hydraulic } \\
\text { Retention } \\
\text { Time (d) }\end{array}$} \\
\hline & & & $\begin{array}{l}\text { Internal } \\
\text { Diameter }\end{array}$ & $\begin{array}{c}\text { Total } \\
\text { Height }\end{array}$ & $\begin{array}{l}\text { Sludge } \\
\text { Filling } \\
\text { Height }\end{array}$ & & \\
\hline WWTP_h & 22,600 & 58 & 8.57 & 3.80 & 3.00 & 173 & 8.95 \\
\hline WWTP_i & 36,200 & 96.6 & 9.43 & 4.36 & 3.50 & 244 & 7.6 \\
\hline WWTP_j & 28,800 & 45.5 & 8.35 & 3.50 & 2.50 & 137 & 9.0 \\
\hline WWTP_k & 35,000 & 70 & 8.50 & 3.80 & 3.00 & 170 & 7.3 \\
\hline
\end{tabular}

The plants listed in Table 2 are ATAD plants consisting of three reactors.

The technology of the autothermal thermophilic stabilization process requires a continuous supply of air (oxygen), as the microorganisms adsorb oxygen supplied to the reactors very quickly. Therefore, it is important to equip the plant with efficient and effective aeration equipment.

The basic technological equipment of the reactors are as follows:

- Central aerators for the mixing and aeration of sludge in the reactors; these aerators are fixed to the operating holes in the reactor floor slab; there is no more than one central aerator in each reactor; the speed is 950 or $1460 \mathrm{rpm}$; the rated motor power of the central aerator is 4.0 or $5.5 \mathrm{~kW}$;

- Helical aerators, which are primarily designed to aerate the sludge and partially mix it; these devices are mounted on the walls of the reactors; each reactor has two to four side aerators; the speed is 1445,1460 , or $1465 \mathrm{rpm}$; the rated motor power of the helical aerator motor is 4.0, 5.5, or $7.5 \mathrm{~kW}$;

- Foam breakers (controllers) designed to limit the formation of coats and excess foam on the boundary between the sludge and air; the breakers, similar to the central aerators, are mounted to the operating holes in the reactor floor slab; the number of foam controllers is two to eight; the speed is $920 \mathrm{rpm}$; the rated motor power is $1.1 \mathrm{~kW}$;

- Internal tube heat exchangers, installed only in the final stage of the installation or in each tank, for possible use of excess energy for the plant's own needs; 
- Control and measuring equipment, consisting of two temperature sensors (one at the $1.0 \mathrm{~m}$ level, the other at the $2.0 \mathrm{~m}$ level above the tank bottom) and a level sensor (mounted at $0.3 \mathrm{~m}$ above the tank bottom);

- $\quad$ Shut-off fittings-gate valves and throttles with actuators.

The total installed power for ATAD in the analyzed sewage treatment plants is presented in Table 3.

Table 3. Total installed power for ATAD in the analyzed sewage treatment plants.

\begin{tabular}{cc}
\hline Subsequent Sludge Treatment Plants (WWTP) & Total Installed Power (kW) \\
\hline WWTP_a & 163.2 \\
WWTP_b & 49.8 \\
WWTP_c & 54.2 \\
WWTP_d & 44.0 \\
WWTP_e & 45.0 \\
WWTP_f & 64.3 \\
WWTP_g & 20.4 \\
WWTP_h & 94.1 \\
WWTP_i & 125.4 \\
WWTP_j & 62.7 \\
WWTP_k & 103.8 \\
\hline
\end{tabular}

Properly functioning sludge management using the process of autothermal thermophilic stabilization requires the use of equipment for the pre-compaction of sludge. Moreover, according to Polish regulations, it is necessary to use equipment for the dewatering of sludge and elimination of odor nuisance.

\section{Process Energy Consumption}

Due to the high rate of oxygen absorption by thermophilic organisms, there are high energy requirements for reactor aeration. An annual energy consumption balance for one of the sewage treatment plants is shown in Table 4.

Table 4. Annual electricity consumption balance sheet.

\begin{tabular}{ccccc}
\hline \multirow{2}{*}{\begin{tabular}{c} 
Measurement $\begin{array}{c}\text { Electricity Consumption (kWh) } \\
\text { Period }\end{array}$ \\
\cline { 2 - 4 }
\end{tabular}} & $\begin{array}{c}\text { For Sludge } \\
\text { Purification }\end{array}$ & $\begin{array}{c}\text { By the ATAD } \\
\text { Installation }\end{array}$ & $\begin{array}{c}\text { In the Sludge } \\
\text { Drainage } \\
\text { Building }\end{array}$ & $\begin{array}{c}\text { Total Electricity } \\
\text { Consumption } \\
\text { (kWh) }\end{array}$ \\
\hline January & 99,732 & 94,980 & 22,560 & 217,272 \\
February & 97,530 & 83,340 & 19,560 & 200,430 \\
March & 90,809 & 88,020 & 23,160 & 201,989 \\
April & 138,259 & 58,200 & 18,240 & 214,699 \\
May & 91,962 & 87,300 & 26,640 & 205,902 \\
June & 88,607 & 71,400 & 21,120 & 181,127 \\
July & 135,844 & 42,840 & 18,840 & 197,524 \\
August & 94,369 & 55,620 & 18,120 & 168,109 \\
September & 86,220 & 66,240 & 19,200 & 171,660 \\
October & 94,219 & 52,920 & 19,920 & 167,059 \\
November & 110,381 & 42,300 & 16,440 & 169,121 \\
December & 112,988 & 62,100 & 21,000 & 196,088 \\
\hline Total: & $1,240,920$ & 805,260 & 244,800 & $2,290,980$ \\
\hline
\end{tabular}

The percentage share of individual technological processes in the total annual electricity consumption in one of the sewage treatment plants is shown in Figure 5. 


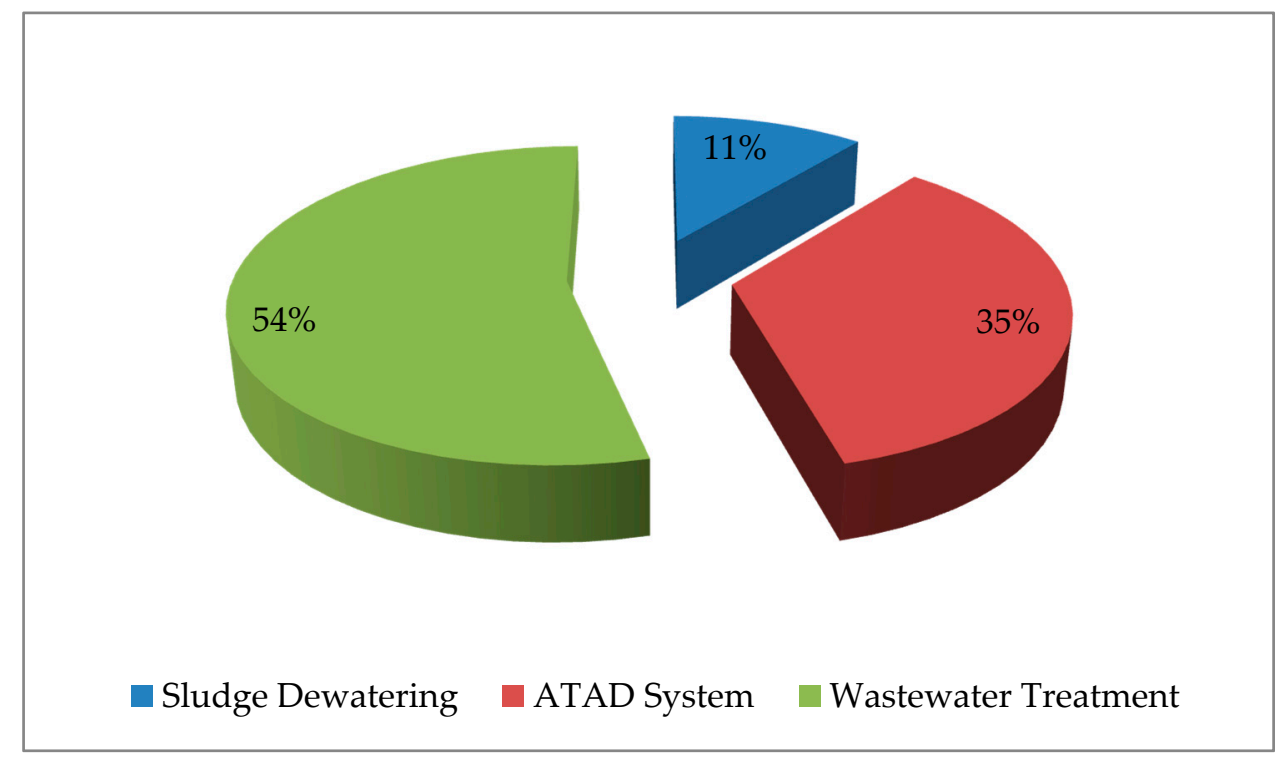

Figure 5. Participation of technological processes in total annual electricity consumption [24].

The knowledge of the energy balance of a sewage treatment plant allows assessing the power consumption by individual processes by means of technical indicators giving the amount of electricity consumption in relation to $1 \mathrm{~m}^{3}$ of treated sewage sludge.

In the examined ATAD installations, the following values of electricity consumption indicators were determined:

- $\quad$ For $1 \mathrm{~m}^{3}$ of sludge to be treated 18.4 to $27.79 \mathrm{kWh}$;

- With regard to $1 \mathrm{~kg}$ of sludge dry matter 0.18 to $0.28 \mathrm{kWh}$.

Unfortunately, there is little information in the scientific literature concerning the energy intensity of the ATAD process - of course, apart from the casual remarks that it is significant. Rojas and others [25] report that the energy consumption rates of ATAD installations operating in Spain and Ireland are 9 to $15 \mathrm{kWh} / \mathrm{m}^{3}$ of sludge processed or 0.3 to $0.5 \mathrm{kWh} / \mathrm{kg}$ of sludge dry matter. According to Archer et al. [26] the energy consumption rate of ATAD installations was $3.9 \mathrm{kWh} / \mathrm{kg}$ of sludge dry matter.

Other technologies of sludge stabilization also cause the increase of energy consumption in sewage treatment plants. Based on the energy consumption in the treatment plant for the process of oxygen stabilization of sludge, the analyzed indicators fluctuate from 6.44 to $13.25 \mathrm{kWh} / \mathrm{m}^{3}$ and from 2.96 to $6.02 \mathrm{kWh} / \mathrm{kg}$ of dry mass [27].

The obvious disadvantage of the ATAD process is the significant electricity consumption $[28,29]$. This is due to the high requirements for reactor aeration. The rate of oxygen absorption by thermophilic organisms is several times higher than in the case of mesophilic organisms. However, with the use of appropriate equipment design and proper operation of the system, costs can be significantly reduced. Processes in the reactors are accompanied by the release of heat, which can be partially recovered by the use of exchangers.

The ATAD process is characterized by a very fast increase of thermophilic bacteria quantity, without the need to inoculate the sediments with the proper microflora. An important advantage is also low sensitivity to temperature fluctuations and resistance to periodic interruptions in system aeration. This guarantees an extremely stable and flexible biological system.

\section{Characteristics of Sewage Sludge}

In the ATAD process, the sludge is transformed into biomass, which can be used in nature. According to Polish legislation, sludge used in agriculture or for land reclamation must meet certain 
conditions. It cannot contain heavy metals in quantities exceeding the applicable limit values. The representative sample of sewage sludge shall not contain Salmonella bacteria or eggs of intestinal parasites Askaris sp., Trichuris sp., Toxocara sp.

Qualitative studies of the sludge were carried out in the existing facilities in the years 2003-2019. The sludge after the ATAD process and dewatering is black-brown and earthy. The sludge hydration ranges from $70 \%$ to $83 \%$ depending on the equipment used. The $\mathrm{pH}$ value of the sludge ranges from 6.5 to 9.3. Detailed changes in the $\mathrm{pH}$ value during the ATAD process are presented by Bartkowska [30].

The organic fraction content in the sludge dry matter is determined by the effectiveness of the stabilization process. Stabilized sludge studied in the analyzed period contained from $29 \%$ to $60 \%$ organic substances [31]. Detailed information on changes in the content of organic substances in sewage sludge subjected to the ATAD process is presented by Bartkowska [32].

The group of indicators characterizing the content of carbon-type organic pollutants includes chemical oxygen demand. The values of chemical oxygen demand in the analyzed period ranged from 51 to $262 \mathrm{~g} \mathrm{O}_{2} / \mathrm{L}$.

Sewage sludge contains biogenic compounds. The quantity of nitrogen and phosphorus compounds in the sludge is important. These substances were determined on the basis of total nitrogen and ammonium nitrogen and total phosphorus concentration. The values of total nitrogen were from 2.4 to $8.1 \%$ of dry matter, while ammonium nitrogen was from 0.8 to $1.8 \%$ of dry matter, and total phosphorus was from 1.1 to $4.2 \%$ of dry matter.

Other compounds found in sewage sludge are calcium and magnesium compounds. In the examined sludge, calcium compounds were present in the amount from 1.6 to $9.2 \%$ of dry matter. The amount of magnesium compounds was found at the level of 0.08 to $1.31 \%$ of dry matter.

Sewage sludge may contain various amounts of heavy metals whose presence depends primarily on the share of industrial wastewater in the total amount of wastewater treated. During the research, small amounts of heavy metals were found. The observed ranges of values of the investigated heavy metals are presented in Table 5.

Table 5. Concentration of heavy metal in the tested sludge.

\begin{tabular}{cc}
\hline Metal & Range of Values (mg/kg of Dry Matter) \\
\hline Cadmium & $0.25-6.12$ \\
Copper & $68-806$ \\
Nickel & $8.6-55.3$ \\
Lead & $4.7-170.2$ \\
Zinc & $328-2396$ \\
Mercury & $0.19-9.30$ \\
Chromium & $12-450$ \\
\hline
\end{tabular}

Within the analyzed period, the concentration of analyzed heavy metals did not exceed the values allowed by the Polish legislation. No significant fluctuation of their concentration in sludge was also found. The concentration of analyzed heavy metals in the examined sludge can range as follows: $\mathrm{Zn}>\mathrm{Cu}>\mathrm{Cr}>\mathrm{Pb}>\mathrm{Ni}>\mathrm{Cd}>\mathrm{Hg}$.

During the process of autothermal thermophilic sludge stabilization, the specific electrolytic conductivity increases. Its value in stabilized sludge ranged from 11,420 to $19,120 \mu \mathrm{S} / \mathrm{cm}$. The results of the study of conductivity changes during the two-stage ATAD process are described by Bartkowska [33]. Higher redox potential was also found in stabilized sludge. Its value oscillated from -561.60 to $-306.40 \mathrm{mV}$. Changes in redox potential were presented by Bartkowska [20].

When examining sewage sludge, particular attention was paid to the effectiveness of its stabilization. During the ATAD process, the content of easily decomposable organic substances is reduced. The minimization of occurring biochemical reactions results in limiting the decomposition of the remaining organic substances in an uncontrolled and burdensome way for the environment. This prevents the sludge from its natural putrescibility tendency and release odorogenic substances. 
We also achieve a visible reduction in the weight of the sludge. There is no clear, legally required definition of the notion of sediment stabilization in Poland. The notion of the so-called technical limit of stabilization is used to assess the degree of sludge stabilization, which causes a reduction in the initial dry organic matter at the level of 38-40\% [34,35]. During the conducted research, it was found that the most numerous range of organic matter content decrease in sludge dry matter is from $37.84 \%$ to $40.25 \%$. Detailed results of the research concerning the decrease in dry matter content, organic substances, and COD values are presented by Bartkowska [32].

A very important task of the sludge treatment plant management is to reduce the risk of the presence pathogenic organisms. Although they have limited capacity to survive in the environment, their resistance varies. Survival is a specific feature characteristic of each microorganism and is also a function of many factors. One of them is the temperature, which in a second stage reactor reaches 55-60 ${ }^{\circ} \mathrm{C}$. In addition, in the ATAD plant, sludge stays for a minimum of $23 \mathrm{~h}$ in each of the reactors, and the hydraulic retention time of sludge in these plants is on average 7.3 to 9.3 full days. One of the important issues connected with the ATAD process is the provision of a stabilized sludge without pathogens [29]. The repeated microbiological testing of sludge after the ATAD process confirmed that it was devoid of the specific DNA of Salmonella sp. and live eggs of the parasites Ascaris sp., Trichuris sp., and Toxocara sp. According to research by López et al. [36] the aerobic thermophilic treatment was the best one also reducing E. coli, while the influence of hydraulic retention times to microbial reduction was non-significant. Thus, the ATAD may possess high potential for reducing biological risks in sewage sludge [37].

\section{Quantities of Generated Sludge}

In all analyzed wastewater treatment plants, sludge is processed in the ATAD plant. These are treatment plants of various sizes, where the average annual weight of generated sludge in 2018 was between 200 and $2479 \mathrm{Mg}$ [38]. The weight of the generated sludge is shown in Figure 6.

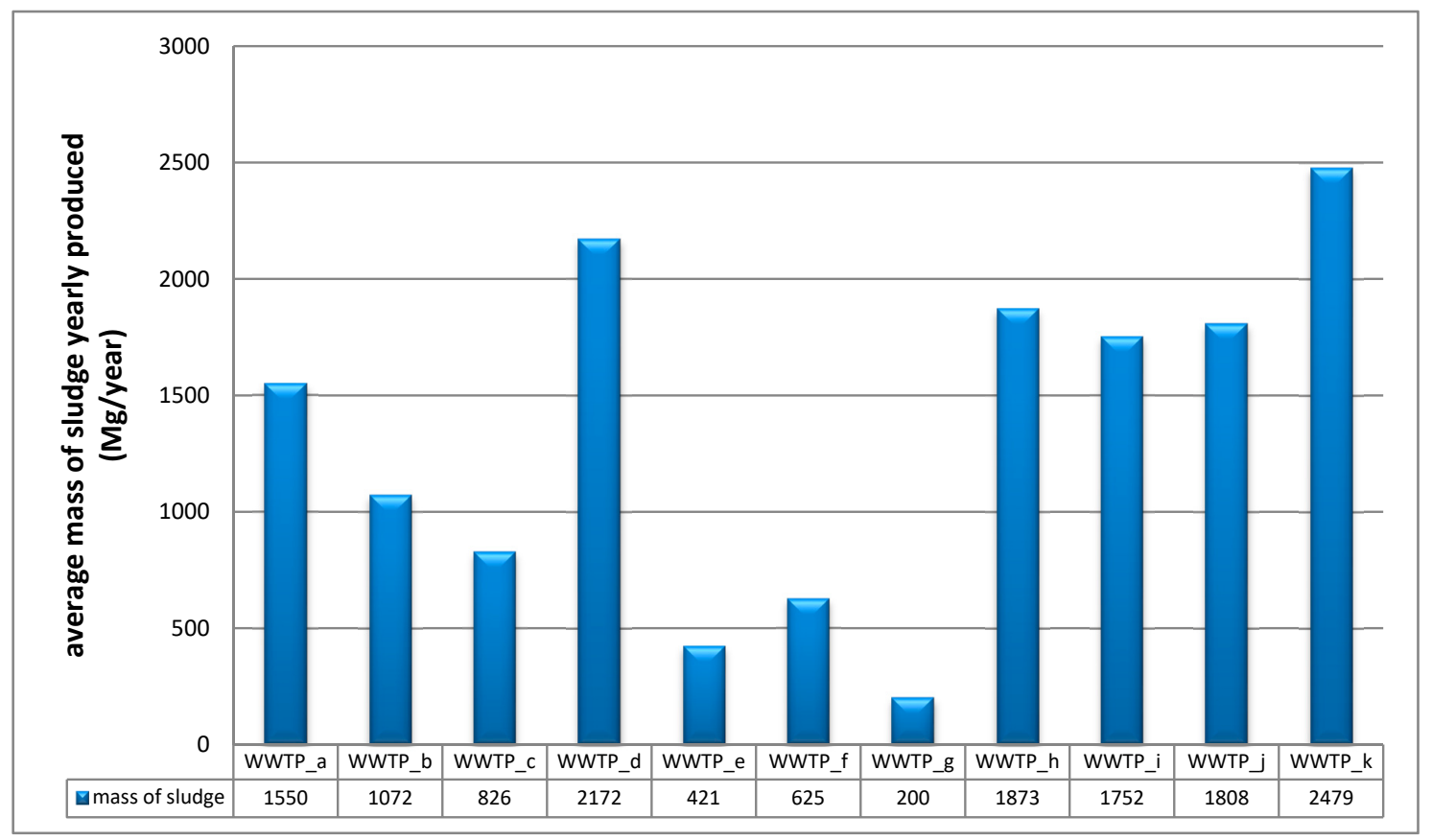

Figure 6. Weight of dehydrated sludge generated in 2018 in the analyzed sewage treatment plants [38].

Each sewage treatment plant keeps a record and waste transfer cards, including the generated sewage sludge. In the analyzed treatment plants, the generated sewage sludge is used in $95-100 \%$ of the natural environment. Municipal sewage sludge is received and utilized by landowners in the surrounding area. The sludge is used on medium and heavy soils. 


\section{Conclusions}

Studies carried out in functioning ATAD installations have confirmed the effectiveness of this process in the gaining of stabilized and hygienized sludge. The process allows obtaining sludge that does not putrify and is free of pathogenic microorganisms, parasites, and fungi. The sludge is sanitary and hygienically safe, while it contains fertilizers, which as a valuable commodity can successfully be returned to the natural cycle.

The conducted analyses showed that sewage sludge can be a good substitute for mineral fertilizers, which, in addition to generating additional environmental problems, also require considerable investment costs. The fertilization of soils with sewage sludge is both economically beneficial and also necessary to restore and maintain ecological balance, as it closes the nutrient cycle in the entire local ecosystem. The best evidence of this is the growing interest of individual farmers in the use of sludge from the analyzed sewage treatment plants. In addition, a certain part of the wastewater treatment plants has been granted a decision by the minister of agriculture and rural development to market organic fertilizer produced from municipal sewage sludge in the ATAD process. Therefore, they should be treated not as a waste but as a source of nutrients recovery.

The impact of the presented installations on the surrounding environment can be analyzed in terms of protection of groundwater and earth surface, protection of surface water, protection against waste, air protection, protection against noise and vibrations, or landscape protection. The use of tight reactor constructions and inter-objective cables ensures the protection of groundwater and the ground surface. Tanks, which are used, are hermetic, and the elimination of odors is achieved by using equipment for the photocatalytic oxidation of odor-generating agents. The noise emission generated by aeration equipment is not higher than $40-50 \mathrm{~dB}$ and does not exceed the boundaries of the plot of the plant.

However, when choosing a sludge management solution based on the ATAD process, one has to take into account the higher operating costs resulting from the use of electricity to aerate the treated sludge.

Author Contributions: I.B., P.B. and I.A.T. conceived and designed the experiments; I.B., P.B. and I.A.T. analyzed the data; I.B. wrote the paper. All authors have read and agreed to the published version of the manuscript.

Funding: The research was carried out as part of research work plan WZ/WBiIŚ/2/2019 at the Bialystok University of Technology and financed from a subsidy provided by the Minister of Science and Higher Education.

Conflicts of Interest: The authors declare no conflict of interest. The founding sponsors had no role in the design of the study; in the collection, analyses, or interpretation of data; in the writing of the manuscript, and in the decision to publish the results.

\section{References}

1. Kominko, H.; Gorazda, K.; Wzorek, Z.; Wojtas, K. Sustainable Management of Sewage Sludge for the Production of Organo-Mineral Fertilizers. Waste Biomass Valoriz. 2018, 9, 1817-1826. [CrossRef]

2. Joo, S.H.; Monaco, F.D.; Antmann, E.; Chorath, P. Sustainable approaches for minimizing biosolids production and maximizing reuse options in sludge management: A review. J. Environ. Manag. 2015, 158, $133-145$. [CrossRef]

3. Kacprzak, M.; Neczaj, E.; Fijałkowski, K.; Grobelak, A.; Grosser, A.; Worwag, M.; Rorat, A.; Brattebo, H.; Almås, Å.; Singh, B.R. Sewage sludge disposal strategies for sustainable development. Environ. Res. 2017, 156, 39-46. [CrossRef]

4. Gherghela, A.; Teodosiua, C.; De Gisib, S. A review on wastewater sludge valorisation and its challenges in the context of circular economy. J. Clean. Prod. 2019, 228, 244-263. [CrossRef]

5. Layden, N.M.; Bartlett, J. Production of biosolids by ATAD from a highly variable municipal source. In Proceedings of the 10th European Biosolids and Biowastes Conference and Workshop, Wakefield, UK, 13-16 November 2005.

6. Ugwuanyi, J.O.; Harvey, L.M.; McNeil, B. Diversity of thermophilic populations during thermophilic aerobic digestion of potato peel slurry. J. Appl. Microbiol. 2008, 104, 79-90. [CrossRef] 
7. Zupančič, G.D.; Roš, M. Aerobic and two-stage anaerobic-aerobic sludge digestion with pure oxygen and air aeration. Bioresour. Technol. 2008, 99, 100-109. [CrossRef]

8. Shugen, L.; Nanwen, Z.; Ping, N.; Xudong, G. Semicontinuous Operation of One-Stage Autothermal Thermophilic Aerobic Digestion of Sewage Sludge: Effects of Retention Time. J. Environ. Eng. 2013, 139, $422-427$.

9. Lasik, M.; Nowak, J. Termofilna tlenowa biodegradacja ścieków i osadów przemysłu spożywczego. Biotechnologia 2006, 3, 98-112. (In Polish)

10. Piterina, A.V.; Bartlett, J.; Pembroke, J.T. Molecular Analysis of Bacterial Community DNA in Sludge Undergoing Autothermal Thermophilic Aerobic Digestion (ATAD): Pitfalls and Improved Methodology to Enhance Diversity Recovery. Diversity 2010, 2, 505-526. [CrossRef]

11. Agarwal, S.; Abu-Orf, M.; Novak, J.T. Sequential polymer dosing for effective dewatering of ATAD sludges. Water Res. 2005, 39, 1301-1310. [CrossRef]

12. Murthy, S.N.; Novak, J.T.; Holbrook, R.D.; Surovik, F. Mesophilic aeration of autothermal thermophilic aerobically digested biosolids to improve plant operations. Water Environ. Res. 2000, 72, 478-483. [CrossRef]

13. Nosrati, M.; Sreekrishnan, T.R.; Mukhopadhyay, S.N. Energy Audit, Solids Reduction, and Pathogen Inactivation in Secondary Sludges during Batch Thermophilic Aerobic Digestion Process. J. Ecol. Eng. 2007, 133, 477-484. [CrossRef]

14. Piterina, A.V.; Bartlett, J.; Pembroke, T.J. Evaluation of the Removal of Indicator Bacteria from Domestic Sludge Processed by Autothermal Thermophilic Aerobic Digestion (ATAD). Int. J. Environ. Res. Public Health. 2010, 7, 3422-3441. [CrossRef]

15. Layden, N.M. An evaluation of autothermal thermophilic aerobic digestion (ATAD) of municipal sludge in Ireland. J. Environ. Eng. Sci. 2007, 6, 19-29. [CrossRef]

16. Csikor, Z.S.; Mihaltz, P.; Hanifa, A.; Kovac, R.; Dahab, M.F. Identification of factors contributing to degradation in autothermal thermophilic sludge digestion. Water Sci. Technol. 2002, 46, 131-138. [CrossRef]

17. Kovács, R.; Kázi, F.; Csikor, Z.; Miháltz, P. Connection between Oxygen Uptake Rate and Carbon Dioxide Evolution Rate in Aerobic Thermophilic Sludge Digestion. Per. Pol. Chem. Eng. 2007, 51, 17-22. [CrossRef]

18. Hepner, S.; Striebig, B.; Regan, R.; Giani, R. Odor generation and control from the Autothermal Thermophilic Aerobic Digestion (ATAD) process. Proc. Water Environ. Fed. 2002, 10, 598-607. [CrossRef]

19. Shanchayan, B.; Parker, W.; Pride, C. Dynamic analysis of a biofilter treating autothermal thermophilic aerobic digestion offgas. J. Environ. Eng. Sci. 2006, 5, 263-272. [CrossRef]

20. Bartkowska, I. Influence of the sewage sludge stabilisation process on the value of its oxidation reduction potential. Environ. Technol. 2014, 35, 2160-2166. [CrossRef]

21. Autoheated Thermophilic Aerobic Digestion ATAD. Available online: https://www.fuchs-germany.com/en/ sewage-sludge/solutions/autoheated-thermophilic-aerobic-digestion-atad/ (accessed on 26 November 2020).

22. Rojas, J.; Burke, M.; Chapwanya, M.; Doherty, K.; Hewitt, I.; Korobeinikov, A.; Meere, M.; McCarthy, S.; O'Brien, M.; Tuoi, V.T.N.; et al. Modeling of Autothermal Thermophylic Aerobic Digestion. Math. Ind. Case Stud. J. 2010, 2, 34-63.

23. Augustin, O.; Little, S. A New Odour Control Option for Sewers and Pump Stations. In Proceedings of the 6th International Conference on Sewer Processes and Networks, Surfers Paradise, Gold Coast, Australia, 7-10 November 2010; International Water Association: London, UK, 2010.

24. Bartkowska, I.; Biedka, P.; Tałałaj, I. Autothermal Thermophilic Aerobic Digestion of Municipal Sewage Sludge in Poland. Review. Proceedings 2020, 51, 12. [CrossRef]

25. Rojas, J.; Zhelev, T.; Graells, M. Energy Efficiency Optimization of Wastewater Treatment-Study of ATAD. In Computer Aided Chemical Engineering; Pierucci, S., Buzzi Ferraris, G., Eds.; Elsevier: Amsterdam, The Netherlands, 2010; Volume 28, pp. 967-972.

26. Archer, G.; Jin, C.; Parker, W. Benchmarking the sustainability of sludge handling systems in small wastewater treatment plants. J. Environ. Manag. 2020, 250, 109893. [CrossRef]

27. Dabrowski, W.; Żyłka, R.; Malinowski, P. Evaluation of energy consumption during aerobic sewage sludge treatment in dairy wastewater treatment plant. Environ. Res. 2017, 153, 135-139. [CrossRef]

28. Pembroke, J.T.; Ryan, M.P. Autothermal Thermophilic Aerobic Digestion (ATAD) for Heat, Gas, and Production of a Class A Biosolids with Fertilizer Potential. Microorganisms 2019, 7, 215. [CrossRef] 
29. Kirilova, E.G.; Vladova, R.K.; Gr Vaklieva-Bancheva, N. Heat integration of two-stage autothermal thermophilic aerobic digestion system for reducing the impact of uncertainty. Energy 2020, 208, 118329. [CrossRef]

30. Bartkowska, I. Changes hydrogen ion exponent of sewage sludge in the process of autothermal thermophilic aerobic digestion. J. Ecol. Eng. 2014, 15, 32-37.

31. Bartkowska, I.; Biedka, P.; Tałałaj, I.A. Analysis of the Quality of Stabilized Municipal Sewage Sludge. J. Ecol. Eng. 2019, 20, 200-208. [CrossRef]

32. Bartkowska, I. Drop in dry mass and organic substance content in the process of autothermal thermophilic aerobic digestion. Process Saf. Environ. Prot. 2015, 98, 170-175. [CrossRef]

33. Bartkowska, I. Drop in conductivity of sewage sludge in the process of autothermal thermophilic aerobic digestion. J. Ecol. Eng. 2017, 18, 67-75. [CrossRef]

34. Borowski, S.; Szopa, J. Experiences with the dual digestion of municipal sewage sludge. Bioresour. Technol. 2007, 98, 1199-1207. [CrossRef]

35. Movahedian, A.H.; Bina, B.; Moeinian, K. Effects of aeration rate and detention time on thermophilic aerobic digestion of mixed sludge and its dewaterability. Int. J. Environ. Sci. Technol. 2005, 2, 105-111.

36. López, A.; Rodríguez-Chueca, J.; Mosteo, R.; Gómez, J.; Ormad, M.P. Microbiological quality of sewage sludge after digestion treatment: A pilot scale case of study. J. Clean. Prod. 2020, 254, 120101. [CrossRef]

37. Jang, H.M.; Choi, S.; Shin, J.; Kan, E.; Kim, Y.M. Additional reduction of antibiotic resistance genes and human bacterial pathogens via thermophilic aerobic digestion of anaerobically digested sludge. Bioresour. Technol. 2019, 273, 259-268. [CrossRef]

38. Bartkowska, I.; Dzienis, L. Utilization of Sewage Sludge after the Process of Autothermal Digestion. J. Ecol. Eng. 2019, 20, 44-49. [CrossRef]

Publisher's Note: MDPI stays neutral with regard to jurisdictional claims in published maps and institutional affiliations. 